\title{
Saccharification and fermentation of pretreated banana leaf waste for ethanol production
}

\author{
Meenakshi Suhag ${ }^{1} \cdot$ Anil Kumar $^{2} \cdot$ Joginder Singh $^{3}$
}

Received: 1 October 2019 / Accepted: 16 July 2020 / Published online: 29 July 2020

(c) Springer Nature Switzerland AG 2020

\begin{abstract}
The present work reveals the potential applicability of banana leaf waste as feedstock for bioethanol production as very less work has been reported on this feedstock. For achieving the same, the performance of crude cellulases of Aspergillus niger JD-11 is explored for saccharification of untreated and pretreated (alkaline, dilute acid and steam) banana leaf waste. Therefore, to determine the best saccharifying conditions, the effects of various parameters such as enzyme loading (5-15 FPU/g), temperature $\left(40-50^{\circ} \mathrm{C}\right)$, surfactant addition $(0.05-0.15 \%$ Tween 80 and PEG 6000$)$ and substrate concentrations (2-6\%) were studied at $150 \mathrm{rpm}$ and $\mathrm{pH}$ 5.0. The crude cellulases yielded maximum reducing sugars $\left(524.83 \mathrm{mg} / \mathrm{g}\right.$ ) from the dilute acid pretreated banana leaf waste at $45^{\circ} \mathrm{C}, 15 \mathrm{FPU} / \mathrm{g}$ enzyme loading and $2 \%$ substrate loading in the presence of $0.15 \%$ PEG $6000(\mathrm{w} / \mathrm{v})$ as surfactant. The fermentation of enzymatic hydrolysate was carried out using initial reducing sugars concentration of $40 \mathrm{~g} / \mathrm{L}$ in the medium at $\mathrm{pH} 5.5,150 \mathrm{rpm}$ and $30^{\circ} \mathrm{C}$ for $30 \mathrm{~h}$ with the help of Saccharomyces cerevisiae. Ethanol production was estimated at every $6 \mathrm{~h}$ and maximum ethanol yield of $0.38 \mathrm{~g} / \mathrm{g}$ sugar and productivity of $1.28 \mathrm{~g} / \mathrm{L} / \mathrm{h}$ was obtained after $12 \mathrm{~h}$ of fermentation of banana leaf waste hydrolysate. Thus, the easily obtained banana leaf waste could be a promising feedstock for bioethanol production.
\end{abstract}

Keywords Pretreatment · Saccharification · Cellulases · Banana leaf waste · Reducing sugars · Surfactants (PEG 6000 and Tween 80) · Fermentation · Ethanol

\begin{tabular}{ll}
\multicolumn{2}{l}{ Abbreviations } \\
LB & Lignocellulosic biomass \\
W/v & Weight/volume \\
SSF & Solid state fermentation \\
MS & Mandels and Sternberg's media \\
rpm & Rotations per minute \\
$\mathrm{mL}$ & Millilitre \\
FPU & Filter paper activity units \\
DNSA & Dinitrosalicylic acid \\
FPase & Filter paperase \\
RS & Reducing sugars \\
PEG & Polyethylene glycol 6000 \\
YPD & Yeast peptone dextrose \\
V/v & Volume/volume
\end{tabular}

\section{Introduction}

To achieve sustainable development as well as to combat the challenges of first generation biofuels, there is huge concern concurrently about the utilization of lignocellulosic materials/wastes which are abundant, easily available and relatively cheaper. Moreover, the bioconversion of these second-generation wastes, generated from many agricultural and forestry activities, to energy can not only promote self-sufficiency but also breed a new industry of jobs and hence economic growth leading to the upliftment of entire society $[5,52,59]$. Worldwide bioethanol articulated itself as most demanding engine fuel because it acts as octane enhancer for cleaner combustion in

Joginder Singh, jssdahiya@gmail.com; Meenakshi Suhag, meenakshisuhag@gmail.com; Anil Kumar, anildhaka2k9@gmail.com $\left.\right|^{1}$ Institute of Environmental Studies, Kurukshetra University, Kurukshetra, Haryana 136119, India. ${ }^{2}$ Department of Botany, Pt. NRS Government College, Rohtak, Haryana 124001, India. ' ${ }^{3}$ aboratory of Environmental Biotechnology, Department of Botany, AlJHM College, Rohtak, Haryana 124001, India. 
unleaded gasoline thereby reducing air pollution [12]. The foremost raw materials utilized for the production of bioethanol are corn in the US and sugarcane in Brazil [6]. Also, there are several studies reported in the literature regarding exploitation of second-generation biofuels, i.e., bioethanol production from different lignocellulosic feedstocks like sugarcane bagasse [36], wheat straw [13], sorghum straw [25], switchgrass [48] and grasses [29] etc. Likewise, banana also represents one of the important fruit crop of tropical and sub tropical regions [1] and generates huge amount ( $220 \mathrm{t} /$ hectare) of waste residues (i.e., stem, leaves and rhizomes) which are primarily lignocellulosic in nature [37] and hence may act as good raw material for the production of bioethanol [53]. Furthermore, banana peels are generally disposed off in the open, as also observed over nearby water-bodies or on roads, which further become one of the greatest causes of environmental pollution [33]. In India, the waste residues of banana fruit constitute a significant factor of urban solid wastes which are difficult to manage under normal conditions and sometimes burnt unethically [7]. Oberoi et al. [31] estimated that more than 1.6 million tonnes of dry banana peels are being produced by India every year which may directly serve as the source of agricultural lignocellulosic waste as its leaf fibers are composed of $\beta-(1-4)$-D glucose units in their crystalline microfibrils of the cellulose chains [60]. Whereas, non-cellulosic matter has $20-25 \%$ hemicellulose, 25-30\% protopectin, $10-12 \%$ lignin, $1-2 \%$ insoluble pectin and the remaining being cellulose [40]. Usually after harvesting the fruits, the leaves are left behind in the field which take many months for their natural degradation [4, 9]. Therefore, using banana waste as lignocellulosic biomass appeared suitable since they are relatively low in lignin [15] but rich in carbohydrates which are necessarily required for bioethanol production.

Lignocellulosic biomass (LB) conversion into bioethanol mainly consists of four basic steps, viz., pretreatment, hydrolysis/saccharification, fermentation and product distillation. The recalcitrant nature of any LB is one of the physical barriers which can be overcome to some extent by using different pretreatment methods to augment the reachable surface area of cellulose which finally boost up the yield of saccharification $[41,56]$. The most commonly used methods for the treatment of different lignocellulosic biomasses are steam, dilute acid and alkali pretreatments [44]. After pretreatment, hydrolysis process is required to hydrolyze the LB into monomeric sugar units which are ultimately fermented into bioethanol. Acid hydrolysis and enzymatic hydrolysis are the two basic methods for saccharification of LB. However, enzymatic hydrolysis of LB is a key approach [46] as it is performed at mild conditions of temperature and $\mathrm{pH}$, having no corrosion problem and usually produces improved glucose yields as compared to acid catalyzed hydrolysis [6, 35, 47]. Enzymatic hydrolysis is commonly accomplished by a battery of hydrolytic and oxidative bacterial and fungal enzymes which are capable to synergistically break down the cellulose, hemicellulose and lignin [34]. The degraded cellulosic monomers are fermented to obtain bioethanol which can be utilized for different purposes after distillation.

In this study, enzymatic hydrolysis of pretreated banana waste with acetone fractionated partially purified cellulases of Aspergillus niger JD-11 was investigated keeping the practical fact of [47] in mind that the main challenges of low yield and high cost of hydrolysis could be overcome by optimizing various process parameters $[18,30]$. Accordingly, the present work was envisaged to analyze the efficient production of fermentable sugars through enzymatic hydrolysis of pretreated banana waste in respect of enzyme loading, temperature, concentration of surfactant as well as substrate.

\section{Materials and methods}

\subsection{Substrate}

Musa paradisiaca $\mathrm{L}$. leaves (= banana leaf waste) were collected from new fruit and vegetable market, Rohtak city $\left(28.8955^{\circ} \mathrm{N}, 76.6066^{\circ} \mathrm{E}\right)$ in Haryana, India. The collected banana leaf waste was washed thoroughly with tap water and finally with distilled water. The banana leaf waste was then dried in the oven at $70^{\circ} \mathrm{C}$ till constant weight, grounded ( 0.2 to $1.0 \mathrm{~mm}$ size) and stored in sealed plastic bag for further use.

\subsection{Pretreatment}

The alkali and acidic pretreatment was carried out by soaking powdered banana leaf waste in aqueous solutions of $0.1 \mathrm{~N} \mathrm{NaOH}$ and $0.1 \mathrm{~N} \mathrm{H}_{2} \mathrm{SO}_{4}$ respectively in the ratio of 1:10 (w/v). For steam pretreatment, powdered banana leaf waste was soaked in distilled water in the ratio of 1:10 $(\mathrm{w} / \mathrm{v})$. The mixture of each flask was autoclaved at $121^{\circ} \mathrm{C}$ for one hour. The pretreated biomass was washed extensively with tap water and finally with distilled water until neutral $\mathrm{pH}$ was obtained. For further use, the pretreated biomass was oven-dried at $70{ }^{\circ} \mathrm{C}$ till constant weight and stored in air tight plastic bags at room temperature.

\subsection{Cellulase production and its harvestation}

Cellulase production by Aspergillus niger JD-11 was achieved under optimized solid state fermentation (SSF). The alkali pretreated dried banana leaf waste $(5 \mathrm{~g})$, with particle size between 0.2 to $1.0 \mathrm{~mm}$, taken 
in $500 \mathrm{~mL}$ Erlenmeyer flasks was moistened with $20 \mathrm{~mL}$ modified Mandels and Sternburg's (MS) basal medium [24] containing ( $\mathrm{g} / \mathrm{l})$ proteose peptone, 2.5,yeast extract, 7.5; $\left(\mathrm{NH}_{4}\right)_{2} \mathrm{SO}_{4}, 10 ; \mathrm{KH}_{2} \mathrm{PO}_{4}, 5.0 ; \mathrm{MgSO}_{4} .7 \mathrm{H}_{2} \mathrm{O}, 0.3$; urea, $0.3 ; \mathrm{CaCl}_{2}, 0.3 ; \mathrm{MnSO}_{4} \cdot \mathrm{H}_{2} \mathrm{O}, 0.0016 ; \mathrm{ZnSO}_{4} .7 \mathrm{H}_{2} \mathrm{O}, 0.0014$; $\mathrm{FeSO}_{4} .7 \mathrm{H}_{2} \mathrm{O}, 0.005 ; \mathrm{CoCl}_{2}, 0.002$ and Tween 80, 0.1\% (v/v). The initial $\mathrm{pH}$ of moistening media was set to 6.0 and autoclaved at $121^{\circ} \mathrm{C}$ for $20 \mathrm{~min}$. Then, the cooled flasks were inoculated with $1.0 \mathrm{~mL}$ of spore suspension having $5 \times 10^{7}$ spores. Spore suspension was prepared from five days old culture slants of Aspergillus niger JD-11 by adding $10 \mathrm{~mL}$ sterilized distilled water containing $0.1 \%$ Tween $80(\mathrm{v} / \mathrm{v})$. All the contents of flasks were mixed well and incubated at $30^{\circ} \mathrm{C}$ under static conditions.

Enzyme harvesting was done on 6th day of incubation period by adding $100 \mathrm{~mL}$ citrate buffer $(0.05 \mathrm{M}, \mathrm{pH}$ 4.8) in each culture flask and then keeping the flasks for one hour at $30{ }^{\circ} \mathrm{C}$ in incubator shaker at $200 \mathrm{rpm}$. The entire slurry was then squeezed through a muslin cloth. The culture extracts were centrifuged at $4{ }^{\circ} \mathrm{C}$ for $15 \mathrm{~min}$ at $10,000 \mathrm{rpm}$ to remove spores and debris. The crude enzyme extract was concentrated by acetone fractionation with increasing volume of solvent. Chilled acetone was added to pre-chilled crude enzyme extract in the ratio of $1: 0.5$ and the mixture was saved at $20^{\circ} \mathrm{C}$ for four hours, followed by centrifugation at $10,000 \mathrm{rpm}$ for $15 \mathrm{~min}$ at $4{ }^{\circ} \mathrm{C}$. For fractional precipitation, the supernatant was regained and acetone was added step by step to further increase the ratio to 1:4. From each step, the pellets were allowed to dry at room temperature to remove the residual acetone. Then, the pellets were resuspended in $2.0 \mathrm{~mL}$ of $0.05 \mathrm{M}$ citrate buffer $(\mathrm{pH} \mathrm{4.8)}$ and dialyzed overnight.

\subsection{Cellulase estimation}

The cellulase activity was measured as filter paper activity units (FPU) according to IUPAC method of [17]. Whatman No. 1 filter paper strip of dimension $1 \times 6 \mathrm{~cm}(\sim 50 \mathrm{mg})$ was placed into each assay tube and were saturated with $1.0 \mathrm{~mL}$ of citrate buffer $(0.05 \mathrm{M}, \mathrm{pH} 4.8)$. After adding $0.5 \mathrm{~mL}$ of appropriately diluted enzyme, the tube was incubated at $50{ }^{\circ} \mathrm{C}$ for one hour in water bath. At the end of incubation period, the enzyme reaction was terminated by the addition of $2.0 \mathrm{~mL}$ of DNSA (Dinitrosalicylic acid) reagent [26]. The tubes were incubated for five minutes in a boiling water bath and the color developed was read at $540 \mathrm{~nm}$ against a reagent blank. Filter paperase (FPase) activity was calculated by following the concept that 0.37 FPU (Filter Paper Unit) of enzyme will release $2.0 \mathrm{mg}$ of glucose under the above assay conditions and was specified as FPUs.

\subsection{Saccharification}

Saccharification of unpretreated, alkaline, dilute acid and steam pretreated banana leaf waste was conducted in $250 \mathrm{~mL}$ screw-capped Erlenmeyer flasks having $50 \mathrm{~mL}$ of $0.05 \mathrm{M}$ citrate buffer ( $\mathrm{pH}$ 5.0) using acetone fractionated crude cellulases of Aspergillus niger JD-11 at $150 \mathrm{rpm}$ for $70 \mathrm{~h}$ in an incubator shaker. One $\mathrm{mL}$ sample was periodically removed from each flask and centrifuged at $4{ }^{\circ} \mathrm{C}$ for $10 \mathrm{~min}$ at 10,000 rpm to remove unhydrolyzed residue and the clear supernatant was analysed for reducing sugars (RS). To find the best saccharification conditions of banana leaf waste, the effect of various factors such as enzyme loading (5-15 FPU/g), temperature $\left(40,45\right.$ and $\left.50{ }^{\circ} \mathrm{C}\right)$, surfactant concentration [0.05-0.15\% Tween $80(\mathrm{v} / \mathrm{v})$; $0.05-0.15 \%$ polyethylene glycol 6000 (PEG 6000) (w/v)] and substrate concentration $[2$ to $6 \%(\mathrm{w} / \mathrm{v})]$ were studied selecting one variable at one time.

\subsection{Analysis of reducing sugars}

The estimation of reducing sugars liberated during enzymatic saccharification was done according to DNSA method [26]. The amount of total reducing sugars was calculated as follows:

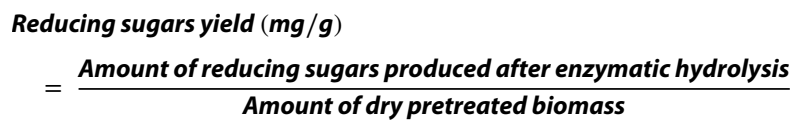

\subsection{Fermentation and ethanol production from enzymatic hydrolysate}

Yeast strain, Sacchromyces cerevisiae (S. cerevisiae), obtained from the Department of Microbiology, Maharishi Dayanand University, Rohtak was maintained on yeast peptone dextrose (YPD) agar slants and was sub-cultured at regular intervals. The fermentation was done in $250 \mathrm{~mL}$ screw-capped Erlenmeyer flasks with a working volume of $100 \mathrm{~mL}$. The fermentation of enzymatic hydrolysate obtained from enzymatic hydrolysis of dilute acid pretreated banana waste was carried out with the help of $S$. cerevisiae. The fermentation was done using initial reducing sugars concentration of $40 \mathrm{~g} / \mathrm{L}$ in the medium at $\mathrm{pH}$ 5.5, $150 \mathrm{rpm}$ and $30^{\circ} \mathrm{C}$ for $30 \mathrm{~h}$ and ethanol production was estimated at every $6 \mathrm{~h}$. The fermentation medium was sterilized by autoclaving at $121^{\circ} \mathrm{C}$ for $15 \mathrm{~min}$, cooled and inoculated with $24 \mathrm{~h}$ old seed culture $(5 \% \mathrm{v} / \mathrm{v})$ of $\mathrm{S}$. cerevisiae. One $\mathrm{mL}$ of the samples was withdrawn at regular intervals and centrifuged at $10,000 \mathrm{rpm}$ for $10 \mathrm{~min}$ at $4{ }^{\circ} \mathrm{C}$. The supernatant was filtered using filters of $0.45 \mu \mathrm{m}$ size 
and the ethanol content was estimated by gas chromatography as outlined in NREL Laboratory Analytical protocol \# 011 [50].

\section{Results and discussion}

To evaluate the effect of pretreatment conditions on the digestibility in comparison with the control or unpretreated condition, enzymatic hydrolysis of alkaline, dilute acid and steam pretreated banana waste was carried out as shown in Fig. 1. The enzymatic hydrolysis was executed at $2 \%$ solid loading $(\mathrm{w} / \mathrm{v}), 10 \mathrm{FPU} / \mathrm{g}$ of crude cellulase dosage, $50^{\circ} \mathrm{C}$ and $150 \mathrm{rpm}$. The reducing sugars produced were estimated at every $10 \mathrm{~h}$ upto $70 \mathrm{~h}$. The reducing sugars attained after enzymatic hydrolysis of pretreated banana waste were found to be ranging from 99.52 to $358.11 \mathrm{mg} / \mathrm{g}$ as compared to unpretreated biomass producing sugars yield of 33.83 to $55.03 \mathrm{mg} / \mathrm{g}$. Maximum reducing sugars of $55.03,157.91,303.70$ and $358.11 \mathrm{mg} / \mathrm{g}$ were obtained respectively from unpretreated, steam, alkali and dilute acid pretreated banana waste after enzymatic hydrolysis in $70 \mathrm{~h}$. However, around $95 \%$ reducing sugars were obtained consistently in the first $40 \mathrm{~h}$ of the enzymatic hydrolysis and therefore no significant increment in the release of reducing sugars could be achieved after $40 \mathrm{~h}$. Corroborative results were also obtained by [10] as well as [19] who obtained maximum reducing sugars after $48 \mathrm{~h}$ of enzymatic hydrolysis. There were $2.86,5.46$, 6.51 times more reducing sugars production from steam, alkali and dilute acid pretreated banana waste respectively as compared to the unpretreated biomass. As the dilute acid pretreated biomass of banana waste yielded maximum reducing sugars during enzymatic hydrolysis, subsequent hydrolysis experiments were carried out using the same biomass only.

\subsection{Effects of enzyme loading on enzymatic hydrolysis}

To analyse the impact of cellulase loading on the yield of reducing sugars, the enzymatic hydrolysis of dilute acid pretreated banana waste was carried out at $2 \%$ solid loading $(\mathrm{w} / \mathrm{v}), 50^{\circ} \mathrm{C}$ and $150 \mathrm{rpm}$ with cellulase dosage of 5 to $15 \mathrm{FPU} / \mathrm{g}$ and the reducing sugars produced were estimated at every $10 \mathrm{~h}$ upto $70 \mathrm{~h}$. With increasing

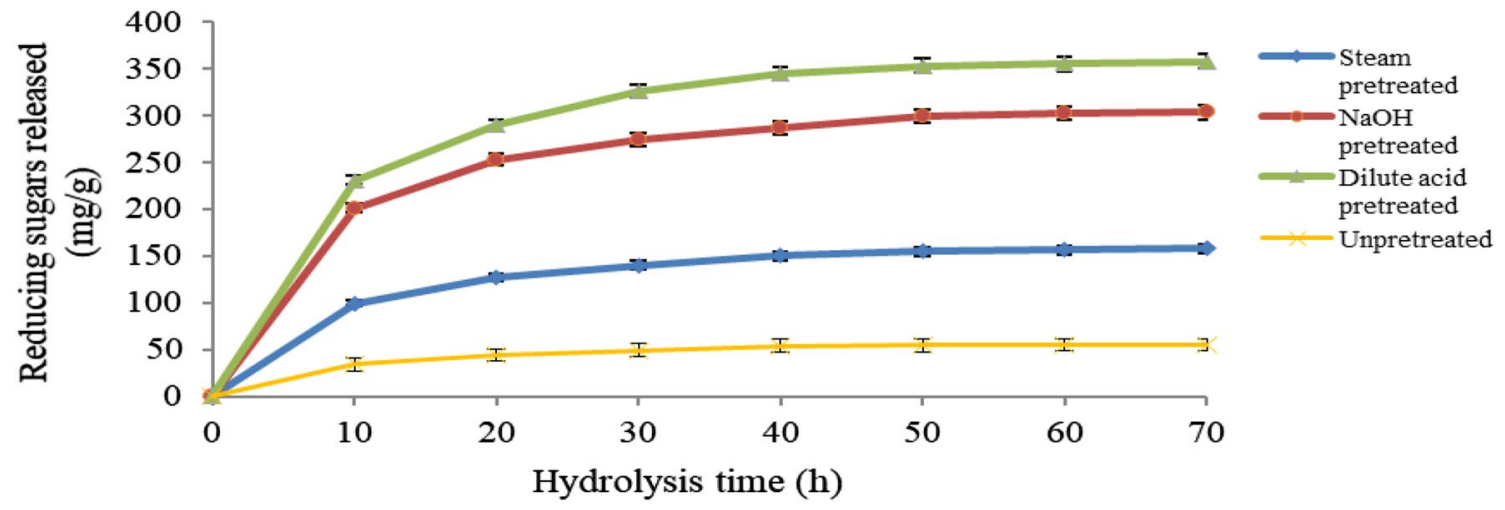

Fig. 1 Enzymatic hydrolysis of differentially pretreated banana waste biomass at enzyme dosage of $10 \mathrm{FPU} / \mathrm{g}$, substrate loading of 2\% (w/v), $\mathrm{pH} 5.0$ and $50^{\circ} \mathrm{C}$

Fig. 2 Effect of enzyme dosage on enzymatic hydrolysis of dilute acid pretreated banana waste biomass at $2 \%$ substrate loading $(\mathrm{w} / \mathrm{v}), \mathrm{pH} 5.0$ and $50^{\circ} \mathrm{C}$

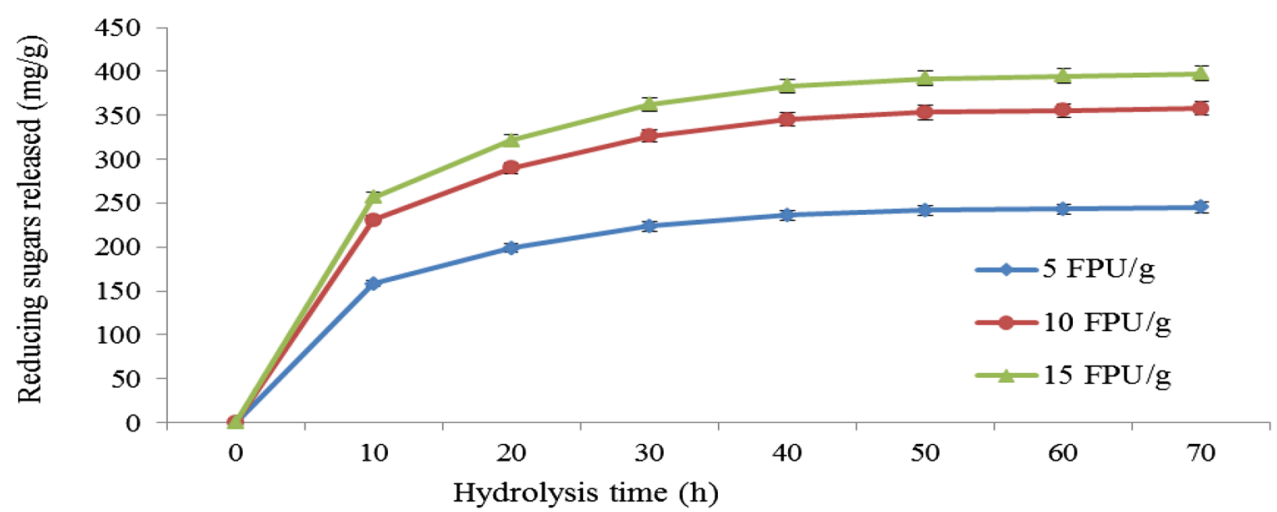


cellulase loading of 5 to $15 \mathrm{FPU} / \mathrm{g}$ Fig. 2, the reducing sugars enhanced from 245.31 to $397.57 \mathrm{mg} / \mathrm{g}$.

An increase of $38 \%$ in the yield of reducing sugars was gained from banana waste at cellulase loading of $15 \mathrm{FPU} / \mathrm{g}$ as compared to cellulase loading of $5 \mathrm{FPU} / \mathrm{g}$. Owing to this reason, the cellulase loading of $15 \mathrm{FPU} / \mathrm{g}$ pretreated substrate was used in rest of the saccharification experiments as the same yielded highest reducing sugars. Corroborative results were also observed by [54] when they found $45 \%$ enhancement in the yield of reducing sugars with the increase in cellulase loading from 3 to $15 \mathrm{FPU} / \mathrm{g}$ pretreated newspapers. However, Rodhe et al. [38] found the optimum enzyme loading of $25 \mathrm{FPU} / \mathrm{g}$ for the maximum hydrolysis of sorghum straw and achieved $70 \%(546 \mathrm{mg} / \mathrm{g}$ ) hydrolysis yield but [3] reported maximum reducing sugars yield of $731 \mathrm{mg} / \mathrm{g}$ from alkali treated water-hyacinth biomass at an enzyme loading of 8 FPUs and $2400 \mathrm{U}$ of $\beta$-glucosidase per gram of the biomass. Collaterally, Kim et al. [22] reported $83 \%$ glucan hydrolysis of ammonia pretreated barley husk at the enzyme loading of $15 \mathrm{FPU} / \mathrm{g}$ glucan while [42] accomplished maximum $59.8 \%$ hydrolysis of $\mathrm{NaOH}$ pretreated sunflower hulls with crude cellulases of Trichoderma reesei at dosage of $25 \mathrm{FPU} / \mathrm{g}$ substrate.

\subsection{Effects of temperature on enzymatic hydrolysis}

To determine the optimum temperature required for saccharification of dilute acid pretreated banana waste, the enzymatic hydrolysis was performed at $40-50{ }^{\circ} \mathrm{C}$ at substrate loading of $2 \%(\mathrm{w} / \mathrm{v})$ in $0.05 \mathrm{M}$ citrate buffer $(\mathrm{pH} 5.0)$ and cellulase loading of $15 \mathrm{FPU} / \mathrm{g}$ for $70 \mathrm{~h}$ and reducing sugars released were estimated at every $10 \mathrm{~h}$. Maximum reducing sugars yield of $346.63,455.91$ and $397.57 \mathrm{mg} / \mathrm{g}$ were achieved respectively at 40,45 and $50^{\circ} \mathrm{C} \mathrm{Fig.} 3$. As the maximum reducing sugars yield was obtained at $45^{\circ} \mathrm{C}$, all the succeeding hydrolysis experiments were performed at $45^{\circ} \mathrm{C}$. Aswathy et al. [3] also accounted maximum reducing sugars yield of $731 \mathrm{mg} / \mathrm{g}$ obtained from alkali treated water-hyacinth biomass at $45^{\circ} \mathrm{C}$. Although Saha and Cotta [39] reported maximum yield of $428 \mathrm{mg} / \mathrm{g}$ of total sugars from pretreated rice hulls at $45^{\circ} \mathrm{C}$ but [55] and [38] found maximum rate of hydrolysis at $50^{\circ} \mathrm{C}$. Thus, the reduced enzyme activity at higher temperature of $50^{\circ} \mathrm{C}$ could have occurred owing to the thermal inactivation of enzymes as also reported by [20].

\subsection{Effects of surfactant addition on enzymatic hydrolysis}

Several studies have reported the enhancement of enzymatic saccharification yields by using various surfactants $[38,57,58]$. In the present study also, the effect of surfactants on enzymatic hydrolysis was investigated by the addition of Tween $80(\mathrm{v} / \mathrm{v})$ and PEG $6000(\mathrm{w} / \mathrm{v})$ in the range of 0.05 to $0.15 \%$. The experiments of enzymatic hydrolysis were conducted at $2 \%$ substrate loading, enzyme dosage of $15 \mathrm{FPU} / \mathrm{g}$ in $0.05 \mathrm{M}$ citrate buffer $(\mathrm{pH} 5.0)$ and $45^{\circ} \mathrm{C}$ and the reducing sugars were estimated at every $10 \mathrm{~h}$ up to $70 \mathrm{~h}$. As presented in Fig. 4, with $0.05,0.1$ and $0.15 \%$ Tween 80 added, hydrolysis of dilute acid pretreated banana waste resulted in maximum reducing sugars yield of $470.39,480.58$ and $501.94 \mathrm{mg} / \mathrm{g}$ respectively, whereas with the addition of $0.05,0.1$ and $0.15 \%$ PEG 6000 , maximum reducing sugars yield of $488.49,510.91$ and $524.83 \mathrm{mg} / \mathrm{g}$ was obtained respectively. Thus, the hydrolysis yield was increased by $3.2,5.4$ and $10.1 \%$ with the addition of 0.05 , 0.1 and $0.15 \%$ Tween 80 and by $7.1,12.1$ and $15.2 \%$ with the addition of $0.05,0.1$ and $0.15 \%$ PEG 6000 respectively as compared to the control. Therefore, the results clearly indicated towards the maximum hydrolysis of the substrate with the addition of $0.15 \%$ PEG $6000(524.83 \mathrm{mg} / \mathrm{g}$ ) as compared to $0.15 \%$ Tween $80(501.94 \mathrm{mg} / \mathrm{g})$. An identical observation was also reported by [23] when they reported that the addition of PEG 6000 at $50 \mathrm{mg} / \mathrm{g}$ biomass of hydrothermally pretreated wheat straw caused an increase of glucose yield by $23 \%$ at $5 \%(\mathrm{w} / \mathrm{w})$ loading. However, the positive effect on enzymatic hydrolysis by addition of PEG on various steam pretreated lignocellulosic substrates was also reported by [45] but [32] claimed that addition of PEG not only enhanced enzymatic hydrolysis yield but also improved enzyme recycling by minimizing the enzyme activity loss owing to adsorption during the hydrolysis which might have occurred because the
Fig. 3 Effect of temperature on enzymatic hydrolysis of dilute acid pretreated banana waste biomass at enzyme dosage of $15 \mathrm{FPU} / \mathrm{g}, 2 \%$ substrate loading $(\mathrm{w} / \mathrm{v})$ and $\mathrm{pH} 5.0$

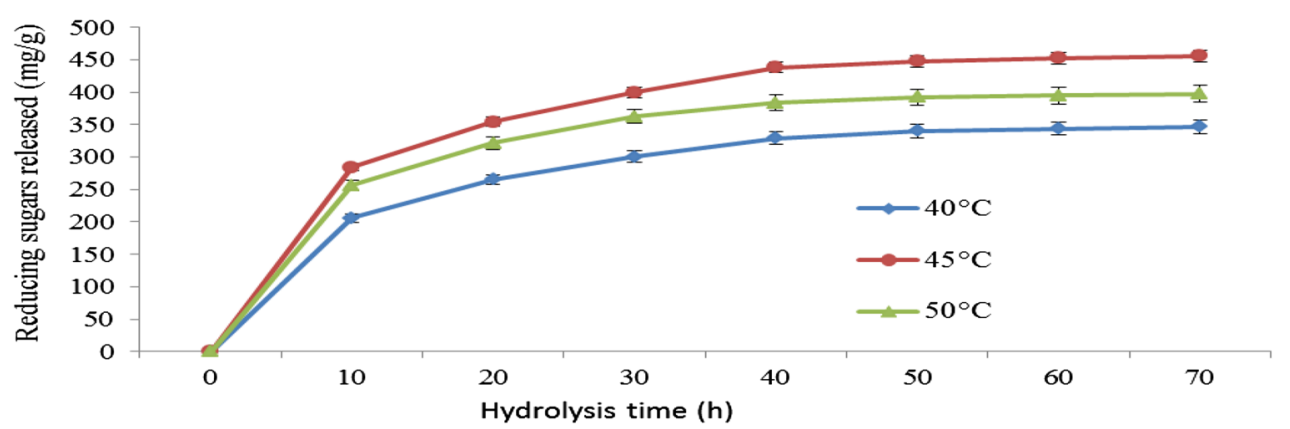

SN Applied Sciences A SPRINGER NATURE journal 


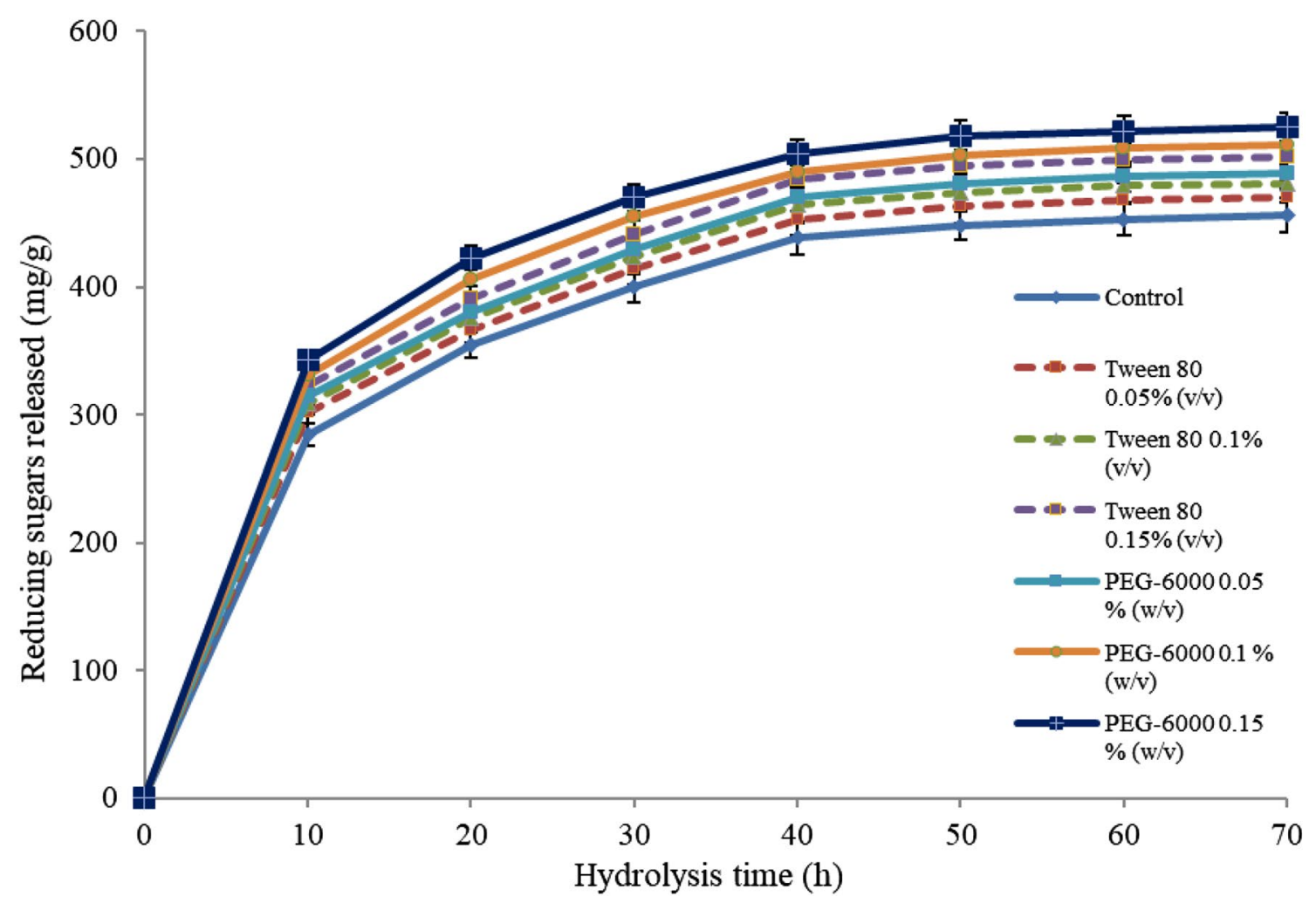

Fig. 4 Effect of different concentrations of surfactants on enzymatic hydrolysis of dilute acid pretreated banana waste at $45^{\circ} \mathrm{C}$, enzyme dosage of $15 \mathrm{FPU} / \mathrm{g}, 2 \%$ substrate loading $(\mathrm{w} / \mathrm{v})$ and $\mathrm{pH} 5.0$

surfactants have been found to increase the enzyme stability by protecting them either from thermal denaturation by shear forces [21] or by adsorption onto lignin preventing the non-productive binding of enzymes to the surface of lignin [14]. Hence, the use of cost-effective surfactants must be investigated further as they could be able to reduce the enzyme loading, enhance enzyme activity and facilitate enzyme recovery and hence diminish the operational cost of the process [2].

\subsection{Effects of substrate concentration on enzymatic hydrolysis}

For analysing the effect of substrate concentration on the enzymatic hydrolysis, the experiments were conducted at different substrate loadings from 2 to $6 \%(\mathrm{w} / \mathrm{v})$ in $0.05 \mathrm{M}$ citrate buffer $(\mathrm{pH} 5.0)$ at cellulase dosage of $15 \mathrm{FPU} / \mathrm{g}$ and $45^{\circ} \mathrm{C}$ and the reducing sugars were estimated at every $10 \mathrm{~h}$ upto $70 \mathrm{~h}$. PEG $6000(0.15 \% \mathrm{w} / \mathrm{v})$ was added in the medium. It was done so as [30] reported that the cellulose conversion was influenced more by the substrate concentration as compared to agitation speed. As depicted in Fig. 5, no significant difference in the yields of reducing sugars could be observed within the substrate loading range of 2 to $6 \%$ during the enzymatic hydrolysis of dilute acid pretreated banana waste. The maximum reducing sugars yields of $524.83,519.98$ and $500.46 \mathrm{mg} / \mathrm{g}$ were obtained at substrate loading of 2,4 , and $6 \%$ respectively. Therefore, the results clearly indicated that $2 \%$ substrate loading yielded maximum reducing sugars from the dilute acid pretreated banana waste. Similar findings were also observed by $[8,11,16,38]$. However, with the increase in substrate concentration, the decrease in hydrolysis yield per gram of substrate might be because of the reduction in aqueous movable phase, inefficient solid mixing and end product inhibition $[28,49]$.

\subsection{Ethanol production from enzymatic hydrolysate}

Figure 6 depicts the time-course of fermentation profile from enzymatic hydrolysate of banana waste and the fermentation parameters are listed in Table 1.

In the present study, highest value of $15.43 \mathrm{~g} / \mathrm{L}$ of ethanol was obtained with ethanol yield of $0.38 \mathrm{~g} / \mathrm{g}$ sugar and productivity of $1.28 \mathrm{~g} / \mathrm{L} / \mathrm{h}$ after $12 \mathrm{~h}$ of fermentation of banana waste hydrolysate, containing initial reducing sugars concentration of $40 \mathrm{~g} / \mathrm{L}$, by Saccharomyces cerevisiae. Corroboratively, maximum ethanol level $(21 \mathrm{~g} / \mathrm{L})$ was reached after $24 \mathrm{~h}$ of fermentation with $20 \%(\mathrm{w} / \mathrm{w})$ banana peels [33] using Kluyveromyces marxianus. Although Singh 

dilute acid pretreated banana waste at different substrate concentrations added with $0.15 \%$ PEG $6000(\mathrm{w} / \mathrm{v})$ at enzyme dosage of $15 \mathrm{FPU} / \mathrm{g}$, pH 5.0 and $45^{\circ} \mathrm{C}$
Fig. 5 Enzymatic hydrolysis of

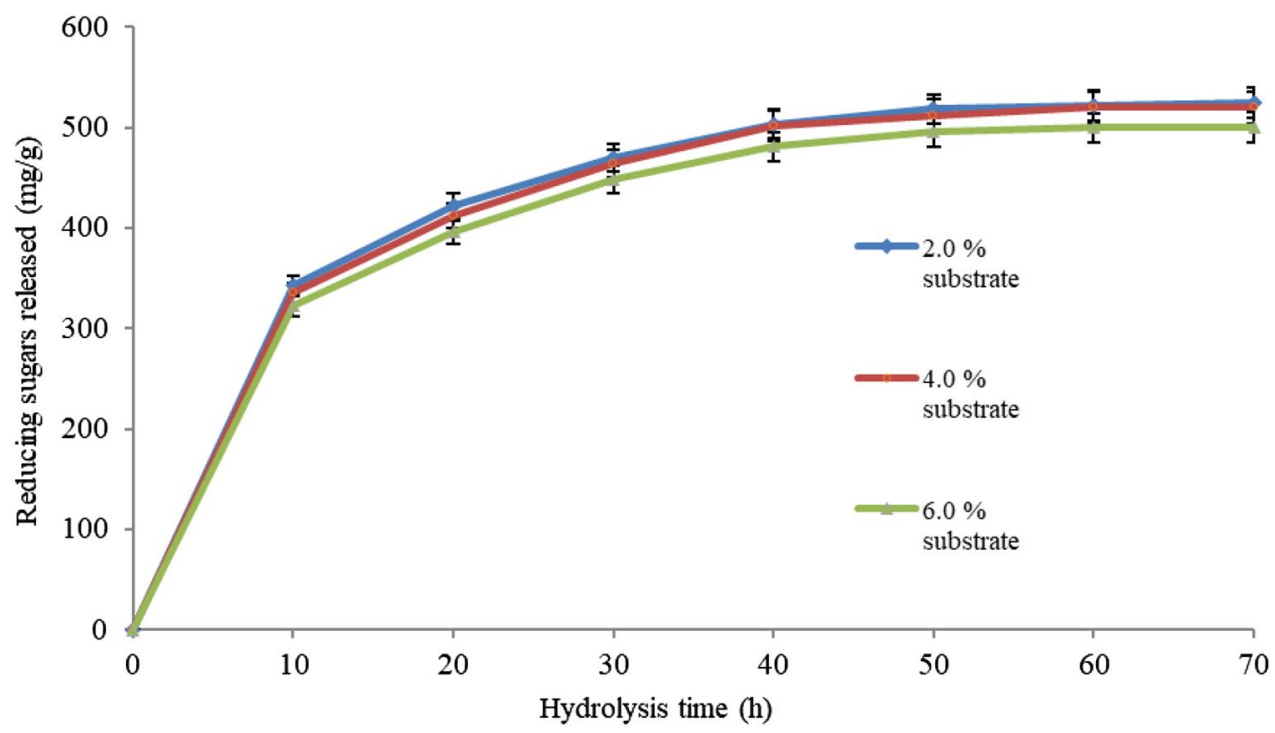

Fig. 6 Time-course of ethano production by $S$. cerevisiae at $30^{\circ} \mathrm{C}$ from enzymatic hydrolysate of banana waste

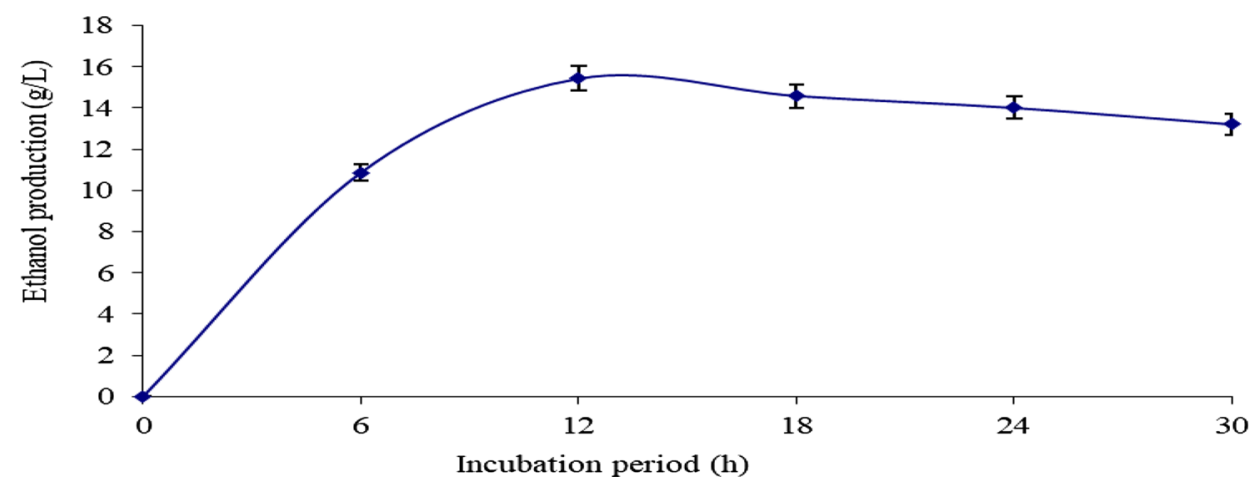

Table 1 Ethanol production from enzymatic hydrolysate using $S$. cerevisiae

\begin{tabular}{lllll}
\hline $\begin{array}{l}\text { Reduc- } \\
\text { ing sugar } \\
\text { concen- } \\
\text { tration in } \\
\text { enzymatic } \\
\text { hydrolysate } \\
\text { (g/L) }\end{array}$ & $\begin{array}{l}\text { Incubation } \\
\text { time }(\mathrm{h})\end{array}$ & $\begin{array}{l}\text { Ethanol } \\
\text { concentra- } \\
\text { tion }(\mathrm{g} / \mathrm{L})\end{array}$ & $\begin{array}{l}\text { Ethanol } \\
\text { yield }(\mathrm{g} / \mathrm{g} \\
\text { sugar) }\end{array}$ & $\begin{array}{l}\text { Ethanol } \\
\text { productivity } \\
(\mathrm{g} / \mathrm{L} / \mathrm{h})\end{array}$ \\
\hline 40 & 12 & $15.43 \pm 0.52$ & $0.38 \pm 0.01$ & $1.28 \pm 0.03$ \\
\hline
\end{tabular}

and Bishnoi [43] obtained ethanol production of $4.3 \mathrm{~g} / \mathrm{L}$ with ethanol volumetric productivity of $0.12 \mathrm{~g} / \mathrm{L} / \mathrm{h}$ and ethanol yield of $0.23 \mathrm{~g} / \mathrm{g}$ by fermentation of water-hyacinth enzymatic hydrolysate with initial reducing sugars concentration of $35 \mathrm{~g} / \mathrm{L}$ using S. cerevisiae but [55] found the maximum ethanol concentration of $12.39 \mathrm{~g} / \mathrm{L}$ after $8 \mathrm{~h}$ of fermentation in the hydrolysate of horticultural waste with ethanol yield and productivity of $0.49 \mathrm{~g} / \mathrm{g}$ of sugar and $1.55 \mathrm{~g} / \mathrm{L} / \mathrm{h}$ respectively. Collateral results were also obtained by [51] who reported the ethanol production of 3.38 and $2.0 \mathrm{~g} / \mathrm{L}$ with yield of 0.54 and $0.40 \mathrm{~g} / \mathrm{g}$ from hydrolysates of fungal pretreated wheat straw and banana stem respectively by using $S$. cerevisiae for fermentation. Likewise, Geng et al. [16] found the ethanol production of $11.69 \mathrm{~g} / \mathrm{L}$ with ethanol yield $0.43 \mathrm{~g} / \mathrm{g}$ and ethanol productivity $1.46 \mathrm{~g} / \mathrm{L} / \mathrm{h}$ from hydrolysate of horticultural waste at eight hours using S. cerevisiae. Moreover, respective ethanol production of 14.4 and $14.9 \mathrm{~g} / \mathrm{L}$ was obtained from enzymatic hydrolysate of water-hyacinth and water lettuce using S. cerevisiae in $9 \mathrm{~h}$ [27].

\section{Conclusion}

In the present study, the banana leaf waste is explored as a potential feedstock for bioethanol production. The feedstock was saccharified by making use of crude cellulases of Aspergillus niger JD-11 under varying conditions. The crude cellulases yielded maximum reducing sugars $(524.83 \mathrm{mg} / \mathrm{g})$ from the dilute acid pretreated banana leaf 
waste at $45^{\circ} \mathrm{C}, 15 \mathrm{FPU} / \mathrm{g}$ enzyme loading and $2 \%$ substrate loading in the presence of $0.15 \%$ PEG $6000(\mathrm{w} / \mathrm{v})$ as surfactant. Then, the fermentation of enzymatic hydrolysate was carried out using initial reducing sugars concentration of $40 \mathrm{~g} / \mathrm{L}$ in the medium at $\mathrm{pH} 5.5,150 \mathrm{rpm}$ and $30^{\circ} \mathrm{C}$ for $30 \mathrm{~h}$ with the help of Saccharomyces cerevisiae. Highest value of $15.43 \mathrm{~g} / \mathrm{L}$ of ethanol with yield of $0.38 \mathrm{~g} / \mathrm{g}$ sugar and productivity of $1.28 \mathrm{~g} / \mathrm{L} / \mathrm{h}$ was obtained after $12 \mathrm{~h}$ of fermentation of the enzymatic hydrolysate. Overall the results and findings provide significant insights that encourage further research in this area in such a way that the abundant banana waste could be envisaged as a budding source of bioethanol production. The ethanol yield may further be enhanced not only by using best recombinant yeast strains which can simultaneously ferment both hexoses and pentoses present in the enzymatic hydrolysate but also by optimization of fermentation parameters.

\section{Compliance with ethical standards}

Conflict of interest All contributing authors declare no conflicts of interest.

\section{References}

1. Albarelli JQ, Rabelo RB, Santos DT, Beppu MM, Meireles MA (2011) Effects of supercritical carbon dioxide on waste banana peels for heavy metal removal. J Supercrit Fluids 58(3):343-351

2. Alkasrawi $M$, Eriksson T, Börjesson J, Wingren $A$, Galbe $M$, Tjerneld F, Zacchi G (2003) The effect of Tween-20 on simultaneous saccharification and fermentation of softwood to ethanol. Enzyme Microb Technol 33(1):71-78

3. Aswathy US, Sukumaran RK, Devi GL, Rajasree KP, Singhania RR, Pandey A (2010) Bio-ethanol from water hyacinth biomass: an evaluation of enzymatic saccharification strategy. Biores Technol 101(3):925-930

4. Baig MMV, Baig MLB, Yasmeen M (2004) Saccharification of banana agro-waste by cellulolytic enzymes. Afr J Biotechnol 3(9):447-450

5. Baig MMV (2005) Cellulolytic enzymes of Trichoderma lignorum produced on banana agro-waste: Optimization of culture medium and conditions. J Sci Ind Res 64:57-60

6. Balat $\mathrm{M}, \mathrm{Balat} \mathrm{H}, \mathrm{O} z \mathrm{C}$ (2008) Progress in bioethanol processing. Prog Energy Combust Sci 34(5):551-573

7. Bhat R, Sujatha S, Balasimha D (2007) Impact of drip fertigation on productivity of arecanut (Areca catechu L.). Agric. Water Manag 90(1-2):101-111

8. Caspeta L, Caro-Bermúdez MA, Ponce-Noyola T, Martinez A (2014) Enzymatic hydrolysis at high-solids loadings for the conversion of agave bagasse to fuel ethanol. Appl Energy 113:277-286

9. Chanakya HN, Sreesha M (2012) Anaerobic retting of banana and arecanut wastes in a plug flow digester for recovery of fiber, biogas and compost. Energy Sustain Dev 16(2):231-235
10. Chandel AK, Singh OV, Rao LV, Chandrasekhar G, Narasu ML (2011) Bioconversion of novel substrate Saccharum spontaneum, a weedy material, into ethanol by Pichia stipitis NCIM3498. Biores Technol 102(2):1709-1714

11. Chen M, Zhao J, Xia L (2009) Comparison of four different chemical pretreatments of corn stover for enhancing enzymatic digestibility. Biomass Bioenergy 33(10):1381-1385

12. Elfasakhany $A$ (2016) Experimental study of dual $n$-butanol and iso-butanol additives on spark-ignition engine performance and emissions. Fuel 163:166-174

13. Erdei B, Barta Z, Sipos B, Réczey K, Galbe M, Zacchi G (2010) Ethanol production from mixtures of wheat straw and wheat meal. Biotechnol Biofuels 3(1):16

14. Eriksson T, Börjesson J, Tjerneld F (2002) Mechanism of surfactant effect in enzymatic hydrolysis of lignocellulose. Enzyme Microb Technol 31(3):353-364

15. Gabhane J, William SP, Gadhe A, Rath R, Vaidya AN, Wate S (2014) Pretreatment of banana agricultural waste for bio-ethanol production: individual and interactive effects of acid and alkali pretreatments with autoclaving, microwave heating and ultrasonication. Waste Manage 34(2):498-503

16. Geng A, Xin F, Ip JY (2012) Ethanol production from horticultural waste treated by a modified organosolv method. Biores Technol 104:715-721

17. Ghose TK (1987) Measurement of cellulase activities. Pure Appl Chem 59(2):257-268

18. Ivetić DŽ, Šćiban MB, Antov MG (2012) Enzymatic hydrolysis of pretreated sugar beet shreds: statistical modeling of the experimental results. Biomass Bioenerg 47:387-394

19. Jeya M, Zhang YW, Kim IW, Lee JK (2009) Enhanced saccharification of alkali-treated rice straw by cellulase from Trametes hirsuta and statistical optimization of hydrolysis conditions by RSM. Biores Technol 100(21):5155-5161

20. Jiménez J, Domínguez JM, Castillón MP, Acebal C (1995) Thermoinactivation of cellobiohydrolase I from Trichoderma reesei QM 9414. Carbohyd Res 268(2):257-266

21. Kaar WE, Holtzapple MT (1998) Benefits from Tween during enzymic hydrolysis of corn stover. Biotechnol Bioeng 59(4):419-427

22. Kim TH, Kim JS, Sunwoo C, Lee YY (2003) Pretreatment of corn stover by aqueous ammonia. Biores Technol 90(1):39-47

23. Kristensen JB, Börjesson J, Bruun $\mathrm{MH}$, Tjerneld $\mathrm{F}$, Jørgensen $\mathrm{H}$ (2007) Use of surface active additives in enzymatic hydrolysis of wheat straw lignocellulose. Enzyme Microbial Technol 40(4):888-895

24. Mandels M, Sternberg D (1976) Recent advances in cellulase technology. J Ferment Technol 54(4):267-286

25. McIntosh S, Vancov T (2010) Enhanced enzyme saccharification of Sorghum bicolor straw using dilute alkali pretreatment. Biores Technol 101(17):6718-6727

26. Miller GL (1959) Use of dinitrosalicylic acid reagent for determination of reducing sugar. Anal Chem 31(3):426-428

27. Mishima D, Kuniki M, Sei K, Soda S, Ike M, Fujita M (2008) Ethanol production from candidate energy crops: water hyacinth (Eichhornia crassipes) and water lettuce (Pistia stratiotes L.). Bioresour Technol 99(7):2495-2500

28. Modenbach AA, Nokes SE (2012) The use of high-solids loadings in biomass pretreatment-a review. Biotechnol Bioeng 109(6):1430-1442

29. Mohapatra S, Mishra SS, Bhalla P, Thatoi H (2019) Engineering grass biomass for sustainable and enhanced bioethanol production. Planta 250:395-412

30. Mussatto SI, Dragone G, Fernandes M, Milagres AM, Roberto IC (2008) The effect of agitation speed, enzyme loading and substrate concentration on enzymatic hydrolysis of cellulose from brewer's spent grain. Cellulose 15(5):711 
31. Oberoi HS, Sandhu SK, Vadlani PV (2012) Statistical optimization of hydrolysis process for banana peels using cellulolytic and pectinolytic enzymes. Food Bioprod Process 90(2):257-265

32. Ouyang J, Dong Z, Song X, Lee X, Chen M, Yong Q (2010) Improved enzymatic hydrolysis of microcrystalline cellulose (Avicel PH101) by polyethylene glycol addition. Biores Technol 101(17):6685-6691

33. Palacios S, Ruiz HA, Ramos-Gonzalez R, Martínez J, Segura E, Aguilar M, Aguilera A, Michelena G, Aguilar C, llyina A (2017) Comparison of physicochemical pretreatments of banana peels for bioethanol production. Food Sci Biotechnol 26(4):993-1001

34. Pérez J, Munoz-Dorado J, De la Rubia TD, Martinez J (2002) Biodegradation and biological treatments of cellulose, hemicellulose and lignin: an overview. Int Microbiol 5(2):53-63

35. Prasad S, Singh A, Joshi HC (2007) Ethanol as an alternative fuel from agricultural, industrial and urban residues. Resour Conserv Recycl 50(1):1-39

36. Rabelo SC, Fonseca NA, Andrade RR, Maciel Filho R, Costa AC (2011) Ethanol production from enzymatic hydrolysis of sugarcane bagasse pretreated with lime and alkaline hydrogen peroxide. Biomass Bioenerg 35(7):2600-2607

37. Reddy GV, Babu PR, Komaraiah P, Roy KR, Kothari IL (2003) Utilization of banana waste for the production of lignolytic and cellulolytic enzymes by solid substrate fermentation using two Pleurotus species (P. ostreatus and P. sajor-caju). Process Biochem 38(10):1457-1462

38. Rodhe AV, Sateesh L, Sridevi J, Venkateswarlu B, Rao LV (2011) Enzymatic hydrolysis of sorghum straw using native cellulase produced by T. reesei NCIM 992 under solid state fermentation using rice straw. Biotech 1(4):207-215

39. Saha BC, Cotta MA (2007) Enzymatic saccharification and fermentation of alkaline peroxide pretreated rice hulls to ethanol. Enzyme and Microbial Technology 41(4):528-532

40. Shah MP, Reddy GV, Banerjee R, Babu PR, Kothari IL (2005) Microbial degradation of banana waste under solid state bioprocessing using two lignocellulolytic fungi (Phylosticta spp. MPS-001 and Aspergillus spp. MPS-002). Process Biochem 40(1):445-451

41. Shamsudin S, Shah UK, Zainudin H, Abd-Aziz S, Kamal SM, Shirai $Y$, Hassan MA (2012) Effect of steam pretreatment on oil palm empty fruit bunch for the production of sugars. Biomass Bioenerg 36:280-288

42. Sharma SK, Kalra KL, Kocher GS (2004) Fermentation of enzymatic hydrolysate of sunflower hulls for ethanol production and its scale-up. Biomass Bioenerg 27(4):399-402

43. Singh A, Bishnoi NR (2013) Comparative study of various pretreatment techniques for ethanol production from water hyacinth. Ind Crops Prod 44:283-289

44. Singh J, Suhag M, Dhaka A (2015) Augmented digestion of lignocellulose by steam explosion, acid and alkaline pretreatment methods: a review. Carbohyd Polym 117:624-631

45. Sipos B, Szilágyi $M$, Sebestyén Z, Perazzini R, Dienes D, Jakab E, Crestini C, Réczey K (2011) Mechanism of the positive effect of poly (ethylene glycol) addition in enzymatic hydrolysis of steam pretreated lignocelluloses. CR Biol 334(11):812-823

46. Suhag M, Kumar A, Singh J (2014) Key technologies for the production of lignocellulolytic enzymes. Environ We Int J Sci Tech 9:39-52
47. Sun Y, Cheng J (2002) Hydrolysis of lignocellulosic materials for ethanol production: a review. Biores Technol 83(1):1-11

48. Suryawati L, Wilkins MR, Bellmer DD, Huhnke RL, Maness NO, Banat IM (2009) Effect of hydrothermolysis process conditions on pretreated switchgrass composition and ethanol yield by SSF with Kluyveromyces marxianus IMB4. Process Biochem 44(5):540-545

49. Szczodrak J, llezuk A, Rogalski J, Leonowicz A (1999) Intensification of oak saw dust enzymatic hydrolysis by chemical or hydrothermal pretreatment. Process Biochem 35:33-41

50. Templeton DW (1994) Determination of ethanol concentration in biomass to ethanol fermentation supernatants by gas chromatography. National Renewable Energy Laboratory; 1994. Laboratory Analytical Procedure\# 011. Revision 05/05/1994

51. Thakur S, Shrivastava B, Ingale S, Kuhad RC, Gupte A (2013) Degradation and selective ligninolysis of wheat straw and banana stem for an efficient bioethanol production using fungal and chemical pretreatment. Biotech 3(5):365-372

52. Wang Z, Qin M, Zhu JY, Tian G, Li Z (2013) Evaluation energy efficiency of bioconversion knot rejects to ethanol in comparison to other thermochemically pretreated biomass. Biores Technol 130:783-788

53. Wobiwo FA, Chaturvedi T, Boda M, Fokou E, Emaga TH, Cybulska I, Deleu M, Gerin PA, Thomsen MH (2019) Bioethanol potential of raw and hydrothermally pretreated banana bulbs biomass in simultaneous saccharification and fermentation process with Saccharomyces cerevisiae. Biomass Convers Biorefinery 9(3):553-563

54. Xin F, Geng A, Chen ML, Gum MJ (2010) Enzymatic hydrolysis of sodium dodecyl sulphate (SDS) - pretreated newspaper for cellulosic ethanol production by Saccharomyces cerevisiae and Pichia stipitis. Appl Biochem Biotechnol 162(4):1052-1064

55. Xin F, Zhang H, Wong W (2013) Bioethanol production from horticultural waste using crude fungal enzyme mixtures produced by solid state fermentation. BioEnergy Res 6(3):1030-1037

56. Xu Z, Wang Q, Jiang Z, Yang XX, Ji Y (2007) Enzymatic hydrolysis of pretreated soybean straw. Biomass Bioenerg 31(2-3):162-167

57. Yao R, Qi B, Deng S, Liu N, Peng S, Cui Q (2007) Use of surfactants in enzymatic hydrolysis of rice straw and lactic acid production from rice straw by simultaneous saccharification and fermentation. BioResources 2(3):389-398

58. Zhang H, Ye G, Wei Y, Li X, Zhang A, Xie J (2017) Enhanced enzymatic hydrolysis of sugarcane bagasse with ferric chloride pretreatment and surfactant. Biores Technol 229:96-103

59. Zhang M, Wang F, Su R, Qi W, He Z (2010) Ethanol production from high dry matter corncob using fed-batch simultaneous saccharification and fermentation after combined pretreatment. Biores Technol 101(13):4959-4964

60. Zuluaga R, Putaux JL, Restrepo A, Mondragon I, Ganán P (2007) Cellulose microfibrils from banana farming residues: isolation and characterization. Cellulose 14(6):585-592

Publisher's Note Springer Nature remains neutral with regard to jurisdictional claims in published maps and institutional affiliations. 